\title{
Professional fulfillment, burnout, and wellness of anesthesiologists during the COVID-19 pandemic
}

\author{
Jennifer M. O'Brien, PhD (1) - Una Goncin, BSc • Richard Ngo, BSc • \\ Peter Hedlin, PhD, MD, FRCPC · Anita Chakravarti, MD, FRCPC
}

Received: 20 December 2020 /Revised: 22 December 2020/Accepted: 23 December 2021 / Published online: 20 January 2021

(C) Canadian Anesthesiologists' Society 2021

\section{To the Editor,}

Prior to the coronavirus disease (COVID-19) pandemic, physicians experienced high levels of stress, emotional exhaustion, burnout, and depression. ${ }^{1}$ During the first wave of the pandemic, healthcare workers were worried about bringing COVID-19 home to their families and shortages of personal protective equipment (PPE) ${ }^{2}$ and reported symptoms of depression, anxiety, insomnia, and distress. ${ }^{3}$

Building on a well-established Anesthesiology Departmental Wellness Program, ${ }^{4}$ we sought to understand the impact of COVID-19 on the wellness of members of the Saskatchewan Provincial Department of Anesthesiology, to describe their major concerns, and to identify coping strategies to inform development of additional wellness supports.

Supplementary Information The online version of this article (https://doi.org/10.1007/s12630-021-01916-4) contains supplementary material, which is available to authorized users.

J. M. O’Brien, PhD (ه) · U. Goncin, BSc $\cdot$ P. Hedlin, PhD, MD, FRCPC

Department of Anesthesiology, Perioperative Medicine and Pain Management, College of Medicine, University of Saskatchewan, Saskatoon, SK, Canada

e-mail: Jennifer.OBrien@usask.ca

R. Ngo, BSc

College of Medicine, University of Saskatchewan, Saskatoon, SK, Canada

A. Chakravarti, MD, FRCPC

Department of Anesthesiology, Perioperative Medicine and Pain Management, College of Medicine, University of Saskatchewan, Saskatoon, SK, Canada

College of Medicine, University of Saskatchewan, Saskatoon, SK, Canada
Following research ethics approval (5 May 2020), we designed a survey (eAppendix in the Electronic Supplementary Material) that combined the quantitative Stanford Physician Wellness Survey's Professional Fulfilment Index (PFI) ${ }^{5}$ with open-ended questions developed de novo. The PFI comprises a six-item professional fulfillment scale and a ten-item overall burnout scale. On the professional fulfillment scale, those with average scores $\geq 3$ are more likely to be professionally fulfilled. On the overall burnout scale, those with average scores $\geq 1.33$ are more likely to be experiencing burnout. The open-ended questions developed de novo were informed by the eight domains of wellness (physical, emotional, intellectual, social, spiritual, occupational, environmental, financial), and pillars of a healthy workplace upon which our department wellness program is based. ${ }^{4}$

All fellowship-trained anesthesiologists, family practice anesthesia providers (FPAs), and anesthesia residents in Saskatchewan received an email invitation circulated by departmental administrative staff in May-June 2020. Descriptive statistics are reported for aggregate survey data, and text responses are reported in a qualitative matrix according to the domains of wellness and a healthy workplace.

Of the 209 invited participants, responses were received from 55 anesthesiologists, four FPAs, and 20 residents (79/ $209=38 \%$ response rate). Respondents were primarily male $(47 / 79,59 \%)$, have been practicing medicine for more than ten years $(47 / 79,59 \%)$, and serve an urban/suburban population $(74 / 79,94 \%)$.

Of the 69 respondents who completed the PFI, 46 (67\%) reported a low level of professional fulfillment and $36 \%$ expressed burnout. Within the past three months, four of the 69 respondents $(6 \%)$ reported making a major medical 
Table Impact on wellness, concerns, and coping strategies: qualitative matrix

\begin{tabular}{|c|c|c|c|}
\hline $\begin{array}{l}\text { Domains of } \\
\text { wellness }\end{array}$ & Impact on wellness & Main concerns & Coping strategies \\
\hline $\begin{array}{l}\text { Working } \\
\text { conditions }\end{array}$ & $\begin{array}{l}\text { A strongly organized systemic response has } \\
\text { made a huge difference day to day } \\
\text { Department leadership and health region and } \\
\text { OR leadership have worked extremely hard } \\
\text { to provide the best pandemic conditions } \\
\text { they were able to } \\
\text { Very supportive environmen. }\end{array}$ & $\begin{array}{l}\text { Continuous bombardment with social } \\
\text { media messaging services... amongst all } \\
\text { colleagues [was] extremely intrusive } \\
\text { and disturbing. } \\
\text { There is an infodemic along with the } \\
\text { pandemic. } \\
\text { Getting COVID-19 because of missing } \\
\text { PPE. }\end{array}$ & $\begin{array}{l}\text { Appreciative of the department } \\
\text { especially the leaders and } \\
\text { colleagues who have stepped up } \\
\text { to the plate. }\end{array}$ \\
\hline $\begin{array}{l}\text { Physical } \\
\text { wellness }\end{array}$ & $\begin{array}{l}\text { I sleep longer and work out more. } \\
\text { I actually have had more time to work out, } \\
\text { run, ... and practice yoga. This is probably } \\
\text { the best state I have been in for years. }\end{array}$ & $\begin{array}{l}\text { I miss going to the gym the most. } \\
\text { Being a frontline health worker and being } \\
\text { in an older age group. } \\
\text { Impact of potential infection on self, } \\
\text { friends, family, colleagues. }\end{array}$ & $\begin{array}{l}\text { More and regular exercise, home } \\
\text { fitness, run, resistance training, } \\
\text { walk, exercise, stretch. }\end{array}$ \\
\hline $\begin{array}{l}\text { Spiritual } \\
\text { wellness }\end{array}$ & $\begin{array}{l}\text { More mindfulness. } \\
\text { I actually have had more time to...meditate. }\end{array}$ & & $\begin{array}{l}\text { Meditation, mindfulness. } \\
\text { Take everything in stride. } \\
\text { Advocate for what is right for } \\
\text { everyone not just myself. }\end{array}$ \\
\hline $\begin{array}{l}\text { Emotional } \\
\text { wellness }\end{array}$ & $\begin{array}{l}\text { This is the least united I have felt with/in my } \\
\text { dept. It feels like everyone had a different } \\
\text { opinion and it is causing more conflict than } \\
\text { usual. } \\
\text { Triggered relapse of mental health condition. }\end{array}$ & $\begin{array}{l}\text { Facing the unknown is stressful. } \\
\text { My chronic depression. } \\
\text { Increased stress causing worse sleep, } \\
\text { more anxiety, and exhaustion. }\end{array}$ & $\begin{array}{l}\text { I have discussed concerns with our } \\
\text { program director and asked for } \\
\text { advice. } \\
\text { Reached out to physicians who } \\
\text { managed my mental health in the } \\
\text { past. }\end{array}$ \\
\hline $\begin{array}{l}\text { Occupational } \\
\text { wellness }\end{array}$ & $\begin{array}{l}\text { Production pressure is down. } \\
\text { Less but more stressful work. } \\
\text { Residents were barred from working. }\end{array}$ & $\begin{array}{l}\text { As a resident, ...I ...feel very frustrated } \\
\text { and helpless with the lack of control I } \\
\text { currently have over my education. }\end{array}$ & $\begin{array}{l}\text { Able to do more non-work. } \\
\text { Have taken more of a leader role } \\
\text { with the pandemic and working } \\
\text { more so more feeling of purpose. }\end{array}$ \\
\hline $\begin{array}{l}\text { Financial } \\
\text { wellness }\end{array}$ & $\begin{array}{l}\text { Having a pandemic services contract has been } \\
\text { good for our income, but because of the } \\
\text { discord between SHA and the physicians } \\
\text { over administration of the contract, there } \\
\text { has been stress and low morale in many of } \\
\text { my colleagues. }\end{array}$ & $\begin{array}{l}\text { Lack of timely payment causing } \\
\text { significant financial distress. }\end{array}$ & I try to limit complaining. \\
\hline Social wellness & $\begin{array}{l}\text { I have been able to spend more time with my } \\
\text { family... At the same time the social } \\
\text { restrictions have made it more stressful by } \\
\text { forcing us to take on non-traditional roles } \\
\text { like educating our children. }\end{array}$ & $\begin{array}{l}\text { I have missed the ability to socialize with } \\
\text { family, friends, and colleagues. } \\
\text { Worrying about older family members. }\end{array}$ & $\begin{array}{l}\text { Spend more quality time with my } \\
\text { kids. } \\
\text { Enjoyed the slower pace and } \\
\text { intimate family time. } \\
\text { Connecting with friends and family } \\
\text { via video. }\end{array}$ \\
\hline $\begin{array}{l}\text { Environmental } \\
\text { wellness }\end{array}$ & $\begin{array}{l}\text { The pace of my life is also considerably } \\
\text { slower and that has been a nice change. I'm } \\
\text { enjoying the time at home with my children } \\
\text { and having time to get caught up on some } \\
\text { stuff. }\end{array}$ & & $\begin{array}{l}\text { I have to specifically work hard to } \\
\text { maintain my wellness because I } \\
\text { can't physically access my usual } \\
\text { supports. }\end{array}$ \\
\hline
\end{tabular}

error (e.g., ordering the wrong medication or lab test) that could have resulted in patient harm. Compared with work before the COVID-19 pandemic, only one-third (23/69, $33 \%$ ) reported they enjoy work just as much, and few (12/ $69,17 \%$ ) reported that morale was high where they work. Many $(42 / 69,61 \%)$ somewhat agreed or strongly agreed that they were more stressed now.

Respondents agreed or strongly agreed that support from family $(57 / 62,91 \%)$, support from colleagues (52/61,
$85 \%$ ), clear communication of directives and disease information about COVID-19 (50/60, 83\%), precautionary measures taken at work (44/59, 75\%), being able to talk to someone about their concerns (45/ $62,73 \%$ ), support from their supervisor/manager/head of department (41/56, 71\%), support from hospital administration $(26 / 52,50 \%)$, their religious convictions (18/42, 43\%), and being able to give feedback to hospital management $(18 / 53,34 \%)$ were helpful in coping with the 
COVID-19 situation. Illustrative quotes from open text responses are reported in a qualitative matrix (Table).

Our results identify the impact of the first wave of the COVID-19 pandemic on the professional fulfillment, burnout, and wellness of anesthesiologists, FPAs, and residents in Saskatchewan, together with their major concerns and coping strategies. Department wellness committees should provide psychologic first aid webinars (including self care and peer support), individualized support to those showing greater need, and continue fostering a workplace culture that promotes resilience and self care. ${ }^{2}$ Department and organizational leadership should strive for clear communication and adequate PPE, and include frontline healthcare providers in decision-making. ${ }^{2}$

Disclosures None.

Funding statement This study was funded through the University of Saskatchewan Dean's Summer Student program.

Editorial responsibility This submission was handled by Dr. Hilary P. Grocott, Former Editor-in-Chief, Canadian Journal of Anesthesia.

\section{References}

1. Canadian Medical Association. CMA NATIONAL PHYSICIAN HEALTH SURVEY: A National Snapshot; October 2018. Available from URL: https://www.cma.ca/sites/default/files/201811/nph-survey-e.pdf (accessed December 2020).

2. Shanafelt T, Ripp J, Trockel M. Understanding and addressing sources of anxiety among health care professionals during the COVID-19 pandemic. JAMA 2020; 323: 2133-4.

3. Lai J, Ma S, Wang $Y$, et al. Factors associated with mental health outcomes among health care workers exposed to coronavirus disease 2019. JAMA Netw Open 2020; . https://doi.org/10.1001/ jamanetworkopen.2020.3976.

4. Chakravarti A, Raazi M, O'Brien J, Balaton B. Anesthesiology resident wellness program at the University of Saskatchewan: concept and development. Can J Anesth 2017; 64: 185-98.

5. Trockel M, Bohman B, Lesure E, et al. A brief instrument to assess both burnout and professional fulfillment in physicians: reliability and validity, including correlation with self-reported medical errors, in a sample of resident and practicing physicians. Acad Psychiatry 2018; 42: 11-24.

Publisher's Note Springer Nature remains neutral with regard to jurisdictional claims in published maps and institutional affiliations. 